\title{
Climatology of growing degree days in Greece
}

\author{
Andreas Matzarakis ${ }^{1, *}$, Dafinka Ivanova ${ }^{2}$, Chris Balafoutis $^{3}$, \\ Timoleon Makrogiannis ${ }^{3}$ \\ ${ }^{1}$ Meteorological Institute, University of Freiburg, Werderring 10, 79085 Freiburg, Germany \\ ${ }^{2}$ Agricultural University, Mendeleev St. 12, 4000 Plovdiv, Bulgaria \\ ${ }^{3}$ Department of Meteorology and Climatology, Aristotle University, 54124 Thessaloniki, Greece
}

\begin{abstract}
Growing degree days (GDD) were calculated for 40 meteorological stations distributed across Greece, on the basis of daily maximum and minimum air temperature $\left(\mathrm{T}_{\mathrm{MAX}}\right.$ and $\mathrm{T}_{\mathrm{MIN}}$, respectively) for the 10 year period from 1978 to 1987. Duration of growing periods (classified in $10 \mathrm{~d}$ intervals) differed among stations. The longest period was from April 1 to November 30, and the shortest from May 1 to September 30. Growing season varies across Greece from about 1600 GDD in the northern mountainous areas to $>2900$ GDD in the lowlands and the southernmost regions. Most spring-sown crops need no more than 1500 GDD to mature; consequently, there are no temperature limitations in Greece for crops such as corn, cotton and tobacco. Despite the sparse climatic network it was possible to create high resolution maps with statistically significant results ( $\mathrm{r}=0.83$ to 0.89 ; $\mathrm{p}=0.95)$, providing reliable information for agricultural planning.
\end{abstract}

KEY WORDS: Growing degree days · Agriculture $\cdot$ Regional maps · Greece

\section{INTRODUCTION}

The most widely cultivated crops grow best at specific optimum temperatures; e.g. corn, tomatoes and sweet peppers are best cultivated at 21 to $23^{\circ} \mathrm{C}$ (Gilmore \& Rogers 1958, Wolf et al. 1986, Bakker \& Uffelen 1988). Because of the differences in the growing season, especially for corn, farmers in Greece need to accurately assess the maturity of their crops to ensure maximum yield quality with low moisture at harvest time. Since corn and many other plants are hybrids, the estimation of maturity is not possible by the traditional 'days to maturity' method, which is based on the time it takes for a plant to grow from seed to harvest. Instead, estimation is conducted on the basis of growing degree days (GDD) as a specific number of GDD - required by the plant to reach maturity, regardless of the number of days taken to accumulate them. Different methods exist for the calculation of GDD, depending on the crop of interest or the personal preferences of the researcher (Gilmore \& Rogers 1958, Perry et al. 1986, McMaster \& Wilhelm 1997).
Our approach differs from the real time estimation of GDD for a field. We describe the climatologic importance of GDD to determine locations and time periods most appropriate for cultivation of corn and other summer crops in Greece. Maps presenting the distribution of GDD in the country during a 10 year period were constructed. This timeframe is accepted as an appropriate period for analysis of daily temperature data (Court 1974).

To calculate the accumulated GDD, the daily growing degree units are usually summed for the number of the days of growth beginning at planting (Darby \& Lauer 2002). For this climatological study, however, the estimation of GDD was carried out for a specified period from the beginning of April to the end of November. Following this estimation we applied a gradual 10 day decrease of the start and end dates, resulting in different growing periods, with the minimum period from May 1 to September 30.

According to these estimations, GDD for the mean growing season in Greece range from about 1600 in the northern and mountainous areas of the country to $>2900$ in the lowlands. These limits exceed the crop maturity 
requirements of most crops: maize 1360-1630, dry beans 1100-1300, sugar beet 1400-1500, barley 1290-1540 (http://en.wikipedia.org/wiki/growing_degree_day).

Detailed GDD information for hybrids can be obtained from seed companies and salesmen. The company ratings should be made using the 30/10 system or other equivalent systems. Commonly, this system with daily higher $\left(30^{\circ} \mathrm{C}\right)$ and lower $\left(10^{\circ}\right)$ temperature limits is used in published weather data (Darby \& Lauer 2002).

The GDD method is used with real data from the field, where thermometers measuring daily maximum and minimum temperature $\left(\mathrm{T}_{\mathrm{MAX}}\right.$ and $\mathrm{T}_{\mathrm{MIN}}$, respectively) are installed in a small shelter. This technique has a wide application in many states of the USA. We intend to use this method in collaboration with interested farmers in Greece. This type of research is still in its infancy and lack of real GDD values prohibits the comparison with plant production.

\section{DATA AND STUDY AREA}

Calculation of daily heat accumulation depends on the availability of datasets on daily $\mathrm{T}_{\mathrm{MAX}}$ and $\mathrm{T}_{\mathrm{MIN}}$. In Greece temperature data are collected by the Hellenic National Meteorological Service (HNMS), the Ministry of Agriculture, and the Ministry for the Environment, Physical Planning and Public Works. Access to these data, however, is very limited. The latter 2 authorities do not publish their data and the HNMS discontinued their publication in 1989. Recent data records of HNMS are in electronic form and available for a high fee, which increases with the volume of data. Therefore, we have analyzed the issue using earlier data published by HNMS (1978-1987) for 40 first class meteorological stations (Table 1, Fig. 1). The majority of these stations have complete data series for the period analyzed (1978-1987).

The following stations had gaps in their data series (missing years in parenthesis): Chalkis (1978, 1979), Chania (1983), Korinthos (1984), Orestias (1982- 1984, 1986), Volos (1983-1985, 1987). The stations used provide an almost complete data coverage of the country.

\section{METHODS}

\subsection{Calculation of growing degree days}

The canonical form for calculating GDD is:

$$
\mathrm{GDD}=\left[\left(\mathrm{T}_{\mathrm{MAX}}+\mathrm{T}_{\mathrm{MIN}}\right) / 2\right]-\mathrm{T}_{\mathrm{BASE}}
$$

Where $\mathrm{T}_{\mathrm{MAX}}$ is the daily maximum air temperature in ${ }^{\circ} \mathrm{C}$ (in our study), $\mathrm{T}_{\mathrm{MIN}}$ is the daily minimum temperature in ${ }^{\circ} \mathrm{C}$, and $\mathrm{T}_{\mathrm{BASE}}$ is the temperature below which growth ceases.
Table 1. Stations of the Greek Meteorological Network used in this study

\begin{tabular}{|c|c|c|c|c|}
\hline \multicolumn{2}{|c|}{ Stn } & \multirow{2}{*}{$\frac{\text { Lat. }\left({ }^{\circ} \mathrm{N}\right)}{38.97}$} & \multirow{2}{*}{$\frac{\text { Long. }\left({ }^{\circ} \mathrm{E}\right)}{21.38}$} & \multirow{2}{*}{$\frac{\text { Alt. (m) }}{46}$} \\
\hline 1 & Agrinio & & & \\
\hline 2 & Alex/polis & 40.85 & 25.95 & 3 \\
\hline 3 & Andravida & 37.92 & 21.30 & 10 \\
\hline 4 & Argostoli & 38.18 & 20.48 & 2 \\
\hline 5 & Arta & 39.17 & 21.00 & 39 \\
\hline 6 & Athens & 37.97 & 23.70 & 10 \\
\hline 7 & Chalkis & 38.47 & 23.60 & 4 \\
\hline 8 & Chania & 35.50 & 24.02 & 62 \\
\hline 9 & Chios & 38.33 & 26.13 & 3 \\
\hline 10 & Filadelfia & 38.05 & 23.67 & 136 \\
\hline 11 & Florina & 40.78 & 21.40 & 650 \\
\hline 12 & Heraklion & 35.33 & 25.18 & 38 \\
\hline 13 & Ierapetra & 35.00 & 45.75 & 16 \\
\hline 14 & Ioannina & 39.67 & 26.85 & 483 \\
\hline 15 & Kalamata & 37.07 & 22.10 & 6 \\
\hline 16 & Kavala & 40.93 & 24.38 & 60 \\
\hline 17 & Kerkyra & 39.62 & 19.92 & 2 \\
\hline 18 & Korinthos & 37.93 & 22.95 & 4 \\
\hline 19 & Kozani & 40.30 & 21.45 & 625 \\
\hline 20 & Kythira & 36.15 & 23.00 & 167 \\
\hline 21 & Lamia & 38.90 & 22.40 & 144 \\
\hline 22 & Larissa & 39.63 & 22.42 & 73 \\
\hline 23 & Lesvos & 39.10 & 26.55 & 2 \\
\hline 24 & Limnos & 39.80 & 25.07 & 13 \\
\hline 25 & Methoni & 36.83 & 21.70 & 33 \\
\hline 26 & Mikra & 40.52 & 22.97 & 4 \\
\hline 27 & Milos & 36.75 & 24.45 & 182 \\
\hline 28 & Naxos & 37.10 & 25.38 & 9 \\
\hline 29 & Orestias & 41.82 & 26.52 & 43 \\
\hline 30 & Patra & 38.25 & 21.73 & 1 \\
\hline 31 & Rhodos & 36.38 & 28.12 & 35 \\
\hline 32 & Samos & 37.03 & 26.92 & 48 \\
\hline 33 & Serres & 41.07 & 23.57 & 32 \\
\hline 34 & Siteia & 35.20 & 26.10 & 25 \\
\hline 35 & Skyros & 38.90 & 24.55 & 4 \\
\hline 36 & Thira & 36.42 & 25.43 & 213 \\
\hline 37 & Trikala & 39.55 & 21.77 & 112 \\
\hline 38 & Tripoli & 37.52 & 22.40 & 512 \\
\hline 39 & Volos & 39.37 & 22.95 & 3 \\
\hline 40 & Zakynthos & 37.78 & 20.88 & 3 \\
\hline
\end{tabular}

$\mathrm{T}_{\text {BASE }}$ varies among species and cultivars (Wang 1960). The quantity $\left(\mathrm{T}_{\mathrm{MAX}}+\mathrm{T}_{\mathrm{MIN}}\right) / 2$ is the mean daily temperature $\left(\mathrm{T}_{\mathrm{AVG}}\right)$, but it is not permissible to replace this quantity with the daily mean temperature, as e.g. $(12+18) / 2=15$, but also $(8+22) / 2=15$. These 2 quantities give the same result, but as we will explain later, they do not have the same biological influence on the plant growing cycle.

Modifications to enhance the biological meaning of Eq. (1) have been suggested by Cross \& Zuber (1972), McMaster \& Smika (1988), Masle et al. (1989) and Wilhelm \& McMaster (1995), who incorporated an upper temperature threshold, added a photoperiodic variable, used maximum or minimum temperature of the day, $\mathrm{T}_{\mathrm{MAX}}$ or $\mathrm{T}_{\mathrm{MIN}}$, or incorporated functions of other environmental factors that affect phenology.

Cross \& Zuber (1972) and Perry et al. (1986) found that Eq. (1) was used in different ways in the literature and that users of the results were unaware of the significant 
Fig. 1. Stations and topography in Greece. Map derived by digitalization of analogical maps of the Army Geographical Service; grid points: $1^{\prime} \times 1^{\prime}(1.8 \times 2.3 \mathrm{~km}$ for Athens $)$

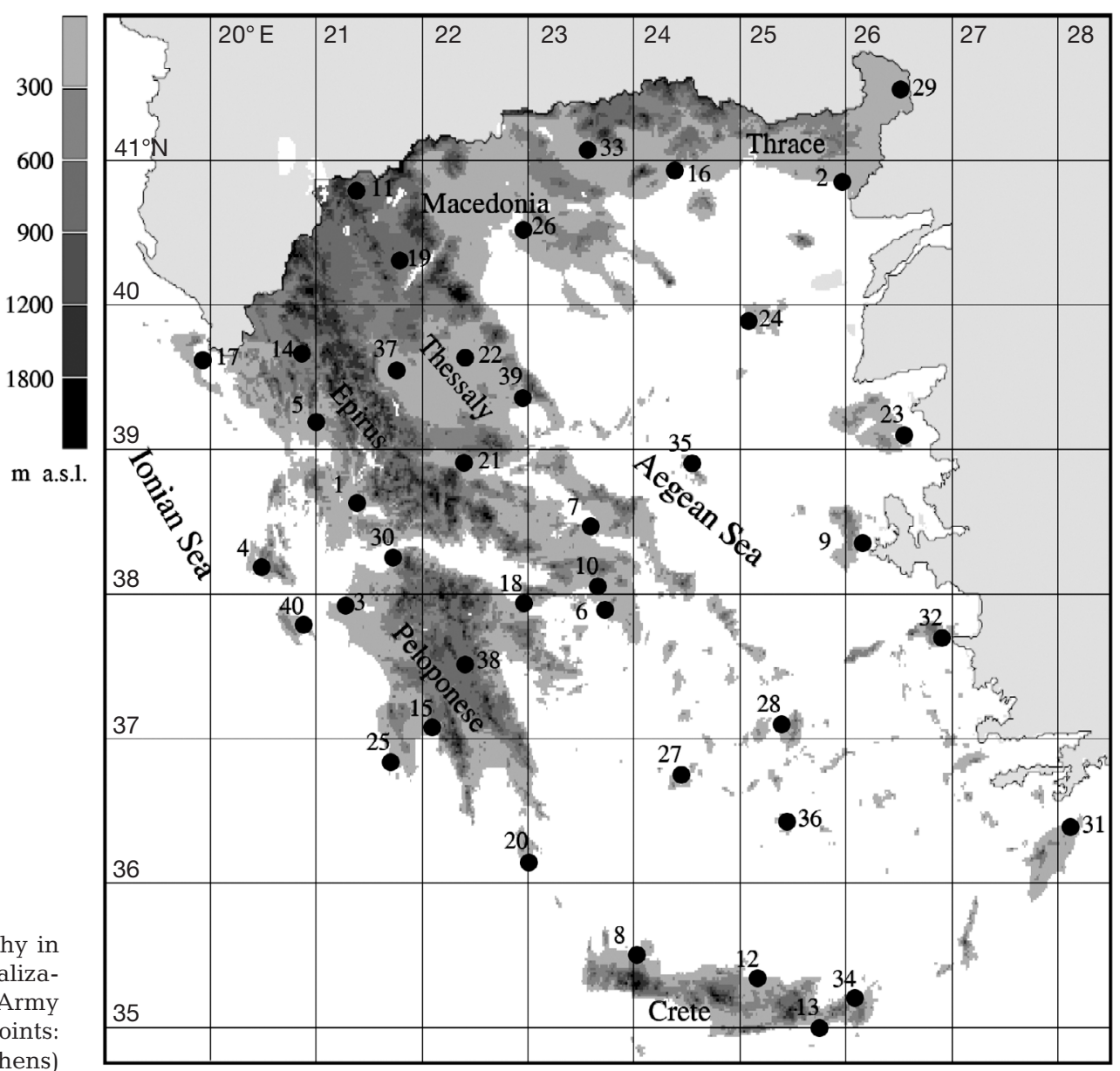

errors that may be introduced by these differences. This problem will create confusion among farmers using differently calculated GDD. To avoid this, we first describe the 2 most common implementations of calculating GDD from Eq. (1). These differ with regard to the way in which $\mathrm{T}_{\mathrm{BASE}}$ is related to the quantity $\left(\mathrm{T}_{\mathrm{MAX}}+\mathrm{T}_{\mathrm{MIN}}\right) / 2$.

In the first approach $\left(\mathrm{T}_{\mathrm{MAX}}+\mathrm{T}_{\mathrm{MIN}}\right) / 2<\mathrm{T}_{\mathrm{BASE}}$, the first term of this inequality takes the form of the equality: $\left(\mathrm{T}_{\mathrm{MAX}}+\mathrm{T}_{\mathrm{MIN}}\right) / 2=\mathrm{T}_{\mathrm{BASE}}$. This method is mostly used by researchers and practitioners involved in small grain production, and also for the calculation of GDD in simulation models.

In the second approach, the separate values of $\mathrm{T}_{\mathrm{MAX}}$ and $\mathrm{T}_{\mathrm{MIN}}$ are compared independently with $\mathrm{T}_{\mathrm{BASE}}$. If $\mathrm{T}_{\mathrm{MAX}}<\mathrm{T}_{\mathrm{BASE}}$ then we adopt the value $\mathrm{T}_{\mathrm{MAX}}=\mathrm{T}_{\mathrm{BASE}}$ and if $\mathrm{T}_{\mathrm{MIN}}<\mathrm{T}_{\mathrm{BASE}}$ then we adopt $\mathrm{T}_{\mathrm{MIN}}=\mathrm{T}_{\mathrm{BASE}}$. This is the most commonly used method in calculating GDD for corn and other crops (e.g. Baker et al. 1986, Wilhelm et al. 1987, 1989, Masoni et al. 1990). The ability to calculate daily GDD accumulation depends on the availability of daily temperature records of $\mathrm{T}_{\mathrm{MAX}}$ and $\mathrm{T}_{\mathrm{MIN}}$, recorded at a height of $1.5 \mathrm{~m}$ above the ground in meteorological shelters.
GDD can be calculated for the winter wheat growing season (September - July) and for corn (April through October). $\mathrm{T}_{\mathrm{BASE}}$ for winter wheat is $0^{\circ} \mathrm{C}$ (McMaster et al. 1994), for corn and other warm season plants it is $10^{\circ} \mathrm{C}$ (Cross \& Zuber 1972).

As our aim was to estimate GDD in Greece during the warm period, we used $10^{\circ} \mathrm{C}$ as $\mathrm{T}_{\mathrm{BASE}}$.

Because in corn and other plants air temperatures greater than a defined upper limit do not improve physiological function, GDDs were calculated on the basis of an upper temperature threshold $\left(\mathrm{T}_{\mathrm{UT}}\right)$. We set this threshold at $30^{\circ} \mathrm{C}$ for corn (Cross \& Zuber 1972) and $25^{\circ} \mathrm{C}$ for wheat (Austin 1990, Curtis et al. 2002).

In conclusion, to estimate the GDD in this study, if $\mathrm{T}_{\mathrm{MAX}}<\mathrm{T}_{\mathrm{BASE}}$ or $\mathrm{T}_{\mathrm{MIN}}<\mathrm{T}_{\mathrm{BASE}}$ their values were replaced by the value of $\mathrm{T}_{\mathrm{BASE}}$.

The original data files for the 40 stations were transformed as described above by a FORTRAN program (source code in Appendix 1). The resulting data sets containing temperature values from 10 to $30^{\circ} \mathrm{C}$ were used for GDD calculation with a second program in FORTRAN (Appendix 2). 


\subsection{Model}

$\mathrm{T}_{\text {MIN }}$ and $\mathrm{T}_{\text {MAX }}$ for each of the 40 stations were tabulated in separate tables for each calendar year. From these tables we chose the data covering the period April 1 to November 30 (244 consecutive days). These 40 tables contained 244 rows and 10 columns comprising the input dataset for the model.

After the model was run, we constructed separate tables of GDD for each of the 40 stations. The daily mean for each station was estimated for each calendar day of the $10 \mathrm{yr}$ period.

There were no significant fluctuations from year to year, as the SD of daily values was very small compared with the 10 yr mean daily value. This small SD of the GDD is due to the cut-off of extreme values $<10^{\circ} \mathrm{C}$ and $>30^{\circ} \mathrm{C}$. Thus the daily temperature range was $20^{\circ} \mathrm{C}$, resulting in small SD values. The coefficient of variation $(\mathrm{CV})$ was small as well $\left(<5^{\circ} \mathrm{C}\right.$ for GDD values up to $2500^{\circ} \mathrm{C}$ )

\subsection{Interpolation}

The Greek Meteorological network is sparse and the data have a local focus, due to the mountainous landscape. Thus, statistical estimation of the GDD alone does not provide farmers with reliable information. To address this problem and provide a more powerful tool for planners, we introduced a second modelling step to interpolate the 'point information' on each station into 'area information', so that every spot in the country will be characterized by a unique value of GDD. The statistical product it is not a simple interpolation, as a number of parameters were taken into account. Similar methods have been applied for data on radiation or heating degree days (Matzarakis \& Balafoutis 2004, Matzarakis \& Katsoulis 2006). The parameters used were longitude, latitude, elevation, and slope aspect; distance from the coastline and the percentage of land and sea in the area were also taken into account. The country was divided into 1 ' grids.

To construct maps of the GDD distribution we selected data from the following growing periods: (1) April 1 to November 30, (2) May 1 to November 30, (3) April 1 to October 31, (4) May 1 to October 31, (5) April 1 to September 30, (6) May 1 to September 30 (Table 2).

Using these data as input files in a statistical procedure, which includes the GDD of the stations as dependent variable and latitude, longitude, elevation, distance to the sea and ratio of land and sea area of the surrounded grids as independent variables, we constructed maps for the above-mentioned time periods. The correlation coefficient $\mathrm{r}$ ranges from 0.83 to 0.89 and the standard error varies between 112 and 134
GDD. The calculated values in the maps do not differ from those obtained from the climate network. The maximum differences between measured and calculated values are $<10 \%$ (4\% for Larissa, $7 \%$ for Orestias, $1 \%$ for Florina, and $2 \%$ for Ierapetra).

\section{RESULTS AND DISCUSSION}

Interannual variability was small; e.g. in Kalamata, the southernmost station of the mainland, estimated values of GDD for the $10 \mathrm{yr}$ period ranged from 2265 in 1978 to 2480 in 1986 . There is a trend of increasing GDD at Florina during the study period (Fig. 2). GDD tended to increase during the study period, confirming the global warming trend.

The mean accumulated daily values were tabulated for the 40 stations over the period from April 1 to November 30 (data not shown). From this table we estimated the GDD for periods ending on August 31, September 30, October 31, and intermediate dates. GDD values for April to November ranged between 1656 in Florina to 2934 GDD in Rhodes.

It is possible to estimate GDD for any time period. If, for example, the starting date is April 25, we subtract the accumulated value corresponding to the previous day (April 24) in the corresponding column of values (e.g. Table 3 for Larissa, chosen because it is located at the geographic midpoint of Greece). For example, during the period from May 10 to September 30 the accumulated GDD are $1637^{\circ} \mathrm{C}$, and from April 20 to August 31 the accumulated GDD are $1506^{\circ} \mathrm{C}$.

Fig. 3 shows the geographic distribution of GDD for April 1 to November 30. In mountainous regions up to $1800 \mathrm{~m}$ the accumulated GDD are $<1600$. In the southernmost coastal regions of the mainland and on the shores of Crete and many islands of the south Aegean Sea the GDD are $>2800$. The magnitude of GDD in-

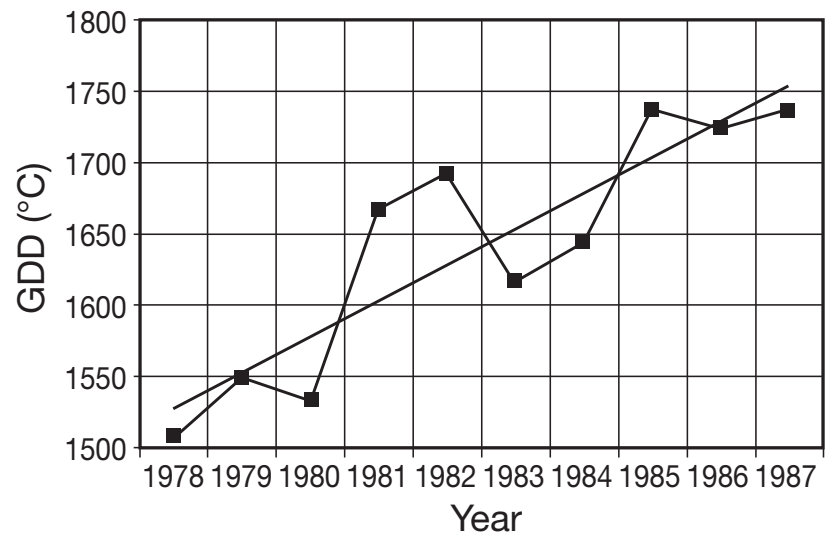

Fig. 2. Growing degree day (GDD) values at Florina from 1978 to 1987 
Table 2. Accumulated GDD starting April 1 and May 1 for map construction

\begin{tabular}{|c|c|c|c|c|c|c|}
\hline \multirow{2}{*}{ Stn } & & \multirow{2}{*}{\multicolumn{2}{|c|}{$\begin{array}{l}\overline{\text { May } 1 \text { to }} \\
\text { Nov. } 30 \text { Oct. } 31\end{array}$}} & \multirow[b]{2}{*}{ Sep. 30} \\
\hline & Nov. 30 & Oct. 31 & Sep. 30 & & & \\
\hline Agrinio & 2318.0 & 2185.0 & 1936.9 & 2160.0 & 2027.0 & 1778.9 \\
\hline Alex/polis & 2001.4 & 1928.8 & 1746.4 & 1894.0 & 1821.4 & 1639.0 \\
\hline Andravida & 2360.3 & 2215.6 & 1952.1 & 2221.3 & 2076.6 & 1813.1 \\
\hline Argostoli & 2569.5 & 2394.5 & 2083.4 & 2420.2 & 2245.2 & 1934.1 \\
\hline Arta & 2354.8 & 2221.1 & 1964.1 & 2205.1 & 2071.4 & 1814.4 \\
\hline Athens & 2681.9 & 2531.2 & 2247.1 & 2522.7 & 2372.0 & 2087.9 \\
\hline Chalkis & 2658.3 & 2523.9 & 2247.3 & 2481.9 & 2347.5 & 2070.9 \\
\hline Chania & 2649.2 & 2475.2 & 2131.2 & 2464.5 & 2290.5 & 1946.5 \\
\hline Chios & 2386.6 & 2261.5 & 2024.7 & 2238.4 & 2113.3 & 1876.5 \\
\hline Filadelfia & 2609.2 & 2486.3 & 2222.1 & 2438.7 & 2315.8 & 2051.6 \\
\hline Florina & 1655.7 & 1701.6 & 1523.5 & 1548.1 & 1594.0 & 1415.9 \\
\hline Heraklion & 2624.8 & 2433.3 & 2126.5 & 2444.7 & 2253.2 & 1946.4 \\
\hline Ierapetra & 2881.8 & 2669.4 & 2328.4 & 2701.1 & 2488.7 & 2147.7 \\
\hline Ioannina & 1979.2 & 1804.1 & 1628.7 & 1867.0 & 1691.9 & 1516.5 \\
\hline Kalamata & 2380.9 & 2225.4 & 1958.1 & 2231.9 & 2076.4 & 1809.1 \\
\hline Kavala & 1986.5 & 1921.6 & 1737.7 & 1871.8 & 1806.9 & 1623.0 \\
\hline Kerkyra & 2422.5 & 2271.0 & 1994.6 & 2279.2 & 2127.7 & 1851.3 \\
\hline Korinthos & 2676.8 & 2498.2 & 2229.3 & 2513.3 & 2334.7 & 2065.8 \\
\hline Kozani & 1795.4 & 1708.1 & 1577.5 & 1700.5 & 1613.2 & 1482.6 \\
\hline Kythira & 2532.2 & 2404.3 & 2122.0 & 2393.2 & 2265.3 & 1983.0 \\
\hline Lamia & 2455.2 & 2349.3 & 2111.3 & 2297.1 & 2191.2 & 1953.2 \\
\hline Larissa & 2201.1 & 2124.9 & 1919.8 & 2059.0 & 1982.8 & 1777.7 \\
\hline Lesvos & 2540.1 & 2416.4 & 2163.0 & 2377.9 & 2254.2 & 2000.8 \\
\hline Limnos & 2197.7 & 2102.8 & 1896.4 & 2077.6 & 1982.7 & 1776.3 \\
\hline Methoni & 2491.2 & 2327.7 & 2028.2 & 2343.1 & 2179.6 & 1880.1 \\
\hline Mikra & 2388.3 & 2307.5 & 2089.0 & 2246.4 & 2165.6 & 1947.1 \\
\hline Milos & 2516.7 & 2366.7 & 2093.6 & 2356.4 & 2206.4 & 1933.3 \\
\hline Naxos & 2531.2 & 2356.1 & 2068.5 & 2359.8 & 2184.7 & 1897.1 \\
\hline Orestias & 1979.0 & 1925.1 & 1759.4 & 1854.3 & 1800.4 & 1634.7 \\
\hline Patra & 2609.1 & 2444.7 & 2141.6 & 2449.8 & 2285.4 & 1982.3 \\
\hline Rhodos & 2933.9 & 2725.6 & 2373.2 & 2730.4 & 2522.1 & 2169.7 \\
\hline Samos & 2649.2 & 2508.4 & 2230.2 & 2488.2 & 2347.4 & 2069.2 \\
\hline Serres & 2211.7 & 2155.9 & 1962.7 & 2065.2 & 2009.4 & 1816.2 \\
\hline Siteia & 2721.0 & 2520.5 & 2209.9 & 2525.4 & 2324.9 & 2014.3 \\
\hline Skyros & 2373.2 & 2250.2 & 2004.8 & 2225.3 & 2102.3 & 1856.9 \\
\hline Thira & 2560.5 & 2392.2 & 2119.9 & 2396.9 & 2228.6 & 1956.3 \\
\hline Trikala & 2421.5 & 2335.8 & 2112.3 & 2258.8 & 2173.1 & 1949.6 \\
\hline Tripoli & 1813.5 & 1742.4 & 1569.4 & 1706.4 & 1635.3 & 1462.3 \\
\hline Volos & 2495.3 & 2401.5 & 2162.8 & 2334.1 & 2240.3 & 2001.6 \\
\hline Zakynthos & 2512.8 & 2349.4 & 2058.1 & 2369.1 & 2205.7 & 1914.4 \\
\hline
\end{tabular}

Table 3. Accumulated growing degree units $\left({ }^{\circ} \mathrm{C}\right)$ for different starting and ending dates in Larissa

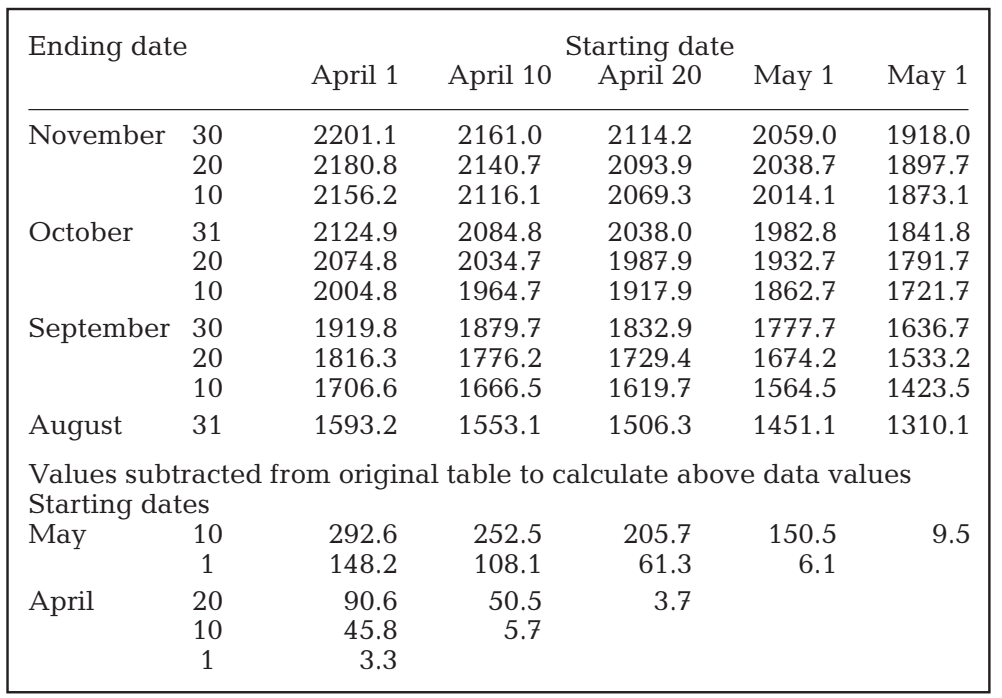

creases from north to south, and from elevated areas to the lowlands.

If the growing season ends $30 \mathrm{~d}$ earlier on October 31 (Fig. 4), the distribution of GDDs is geographically the same, but GDD is 200 units lower; the reduction is more pronounced in the mountains. For April 1 to September 30, areas $>700 \mathrm{~m}$ have <1200 GDD (Fig. 5). The lowland area of the country shows predominance of 1800-2000 GDD. In elevations $\leq 650 \mathrm{~m}$, 1400-1600 GDD are common. Peloponnesus, Crete and south Aegean islands have higher values.

For a more complete description of the distribution of the accumulated GDD, 3 more periods starting on May 1st were considered with the ending day remaining the same as in the previous analyses (Table 3, last 3 columns). Using these data we constructed 3 maps (Figs. 6, 7 \& 8) showing the geographical distribution of the GDD over Greece for these shorter and warmer periods.

During the period May 1 to November 30 (Fig. 6) GDD values range from 2600 on Crete and Rhodes to $<1200$ in mountainous areas. The geographical distribution of the GDD of a shorter period (May 1 to October 31; Fig. 7) shows a lower upper limit of GDD in comparison with Fig. 6. Data for a period of 5 mo (May 1 to September 30) are given in Fig. 8.

There are no comparable data in the literature on climate regions that have similar characteristics or are located at the same latitude.

\section{CONCLUSIONS}

The method used to calculate GDD and the mapping method applied showed that it is possible to use high- or low-density climate networks together with geo-statistical techniques, to produce reliable spatial data (maps) and valuable information for agriculture management.

The shortest period studied, May 1 to September 30, can be characterized climatologically as a time period that permits achievement of crop maturity in corn, cotton, tobacco, sugar beets and other plants without temperature limitations, as the entire lowland area has GDD >1600. Land up to an altitude of $650 \mathrm{~m}$ has GDD > 1200 . 


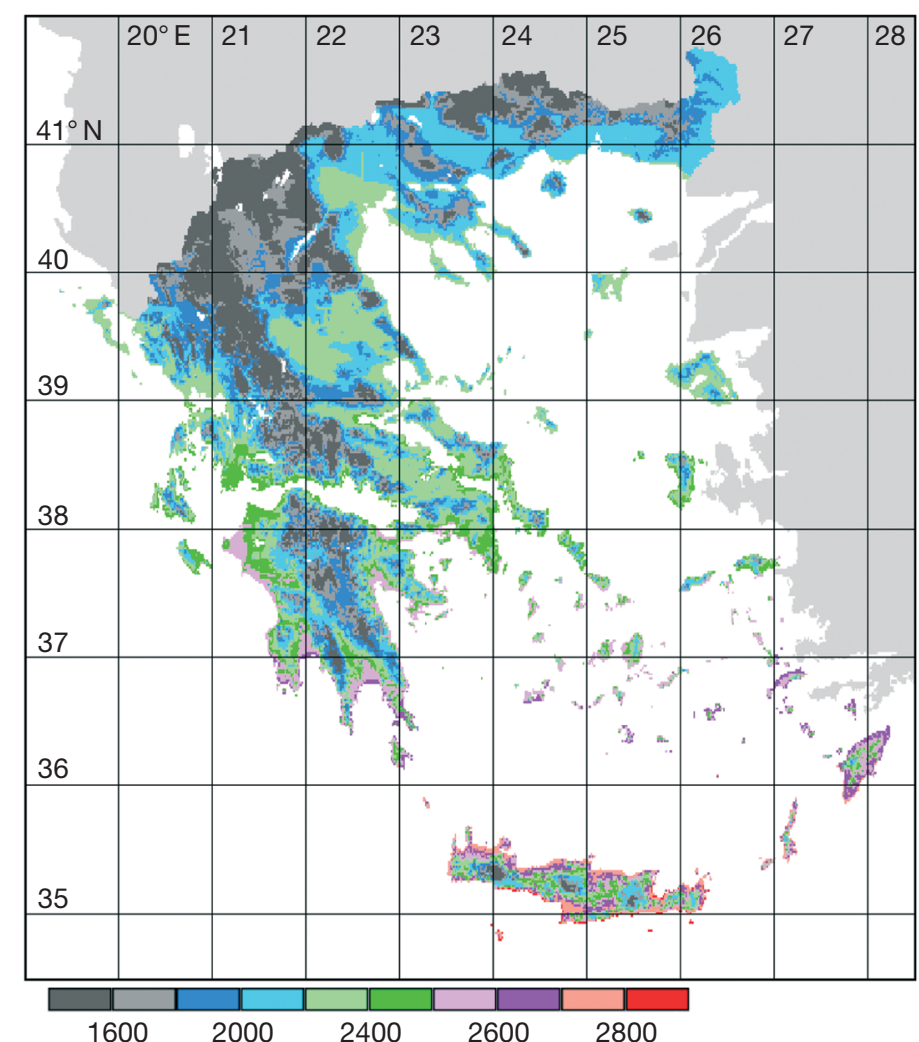

Fig. 3. GDD $\left({ }^{\circ} \mathrm{C}\right)$ in Greece for April 1 to November 30

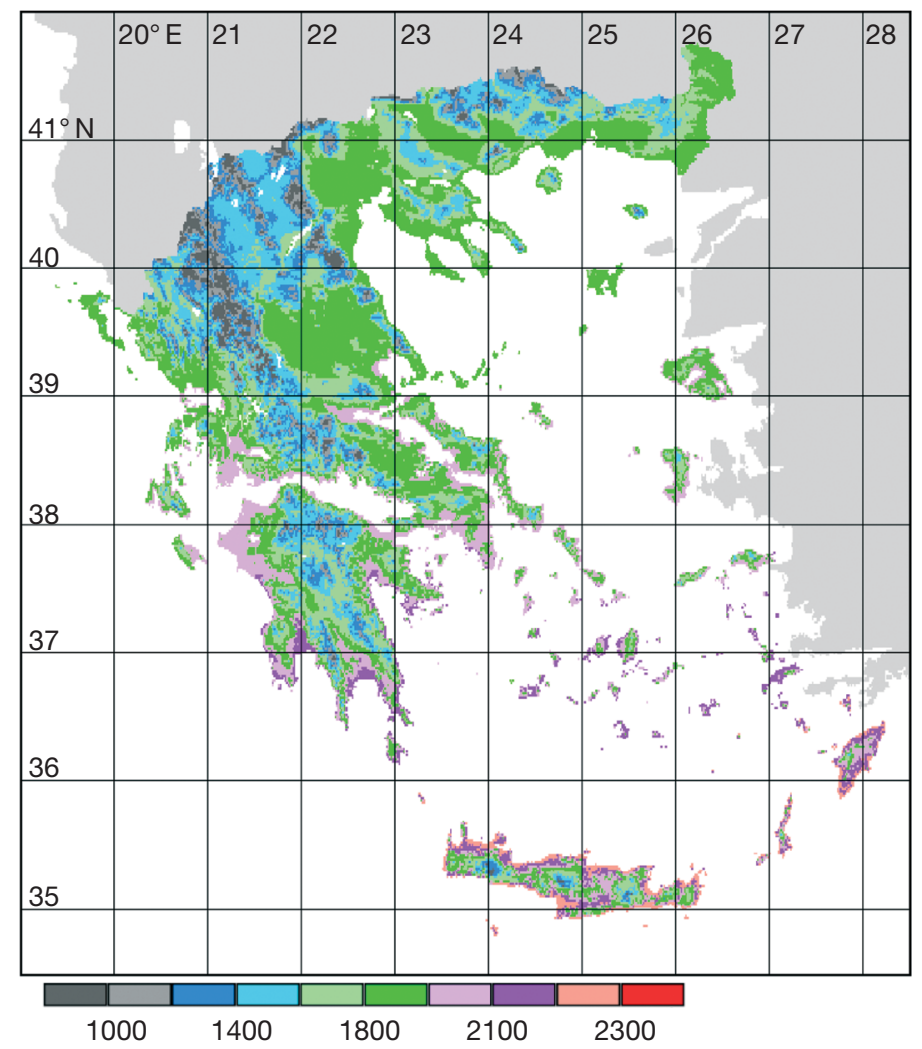

Fig. 5. GDD $\left({ }^{\circ} \mathrm{C}\right)$ in Greece for April 1 to September 30

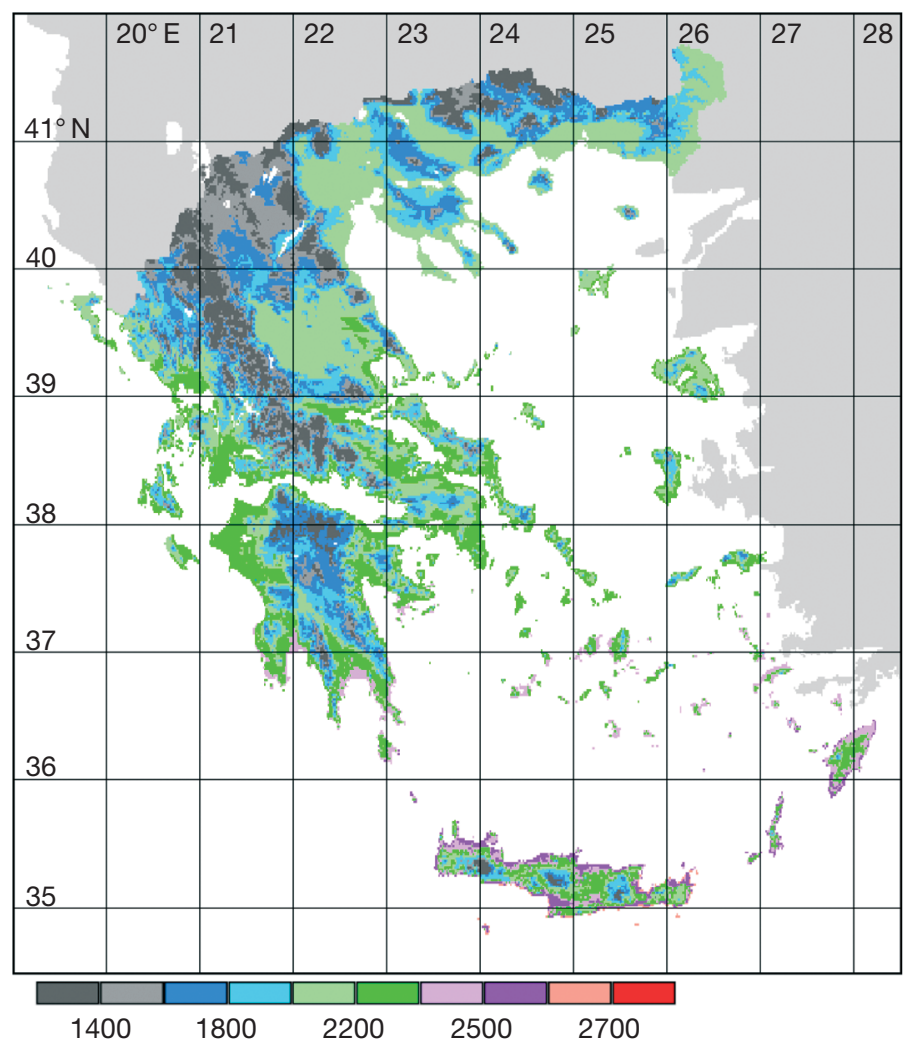

Fig. 4. GDD ( $\left.{ }^{\circ} \mathrm{C}\right)$ in Greece for April 1 to October 31

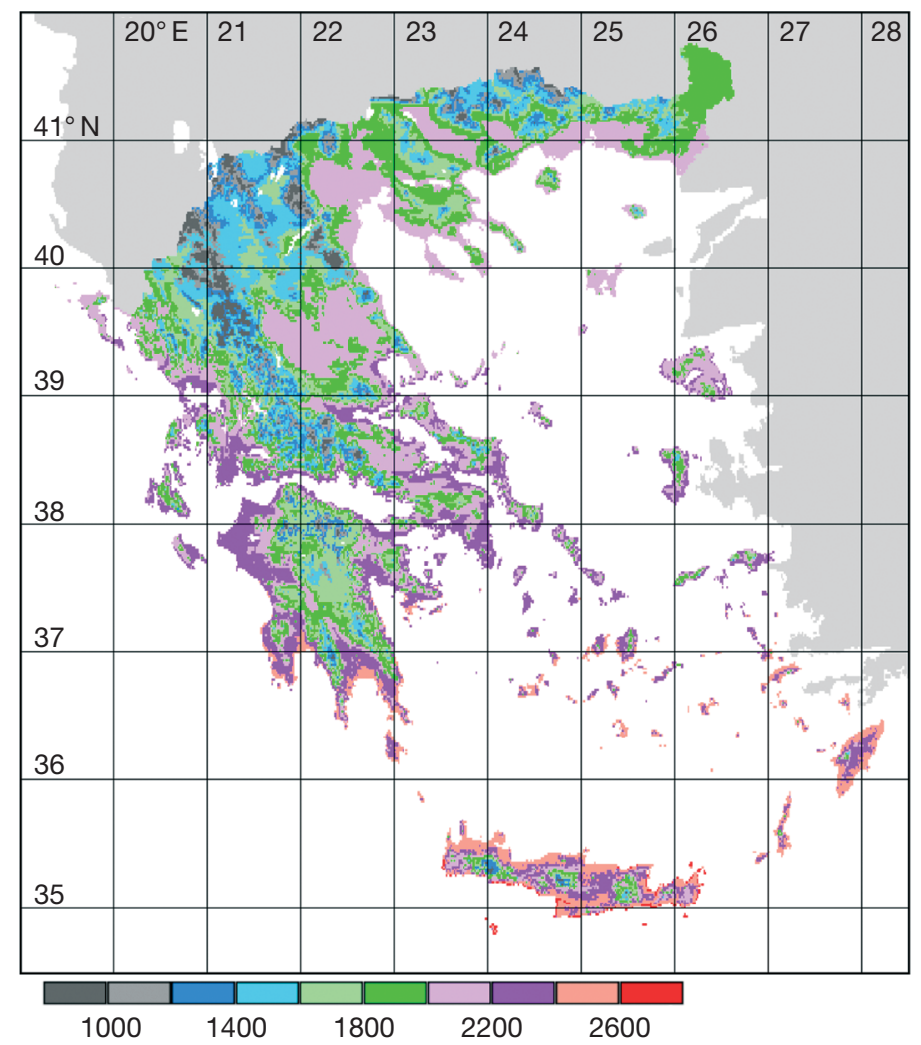

Fig. 6. GDD $\left({ }^{\circ} \mathrm{C}\right)$ in Greece May 1 to November 30 


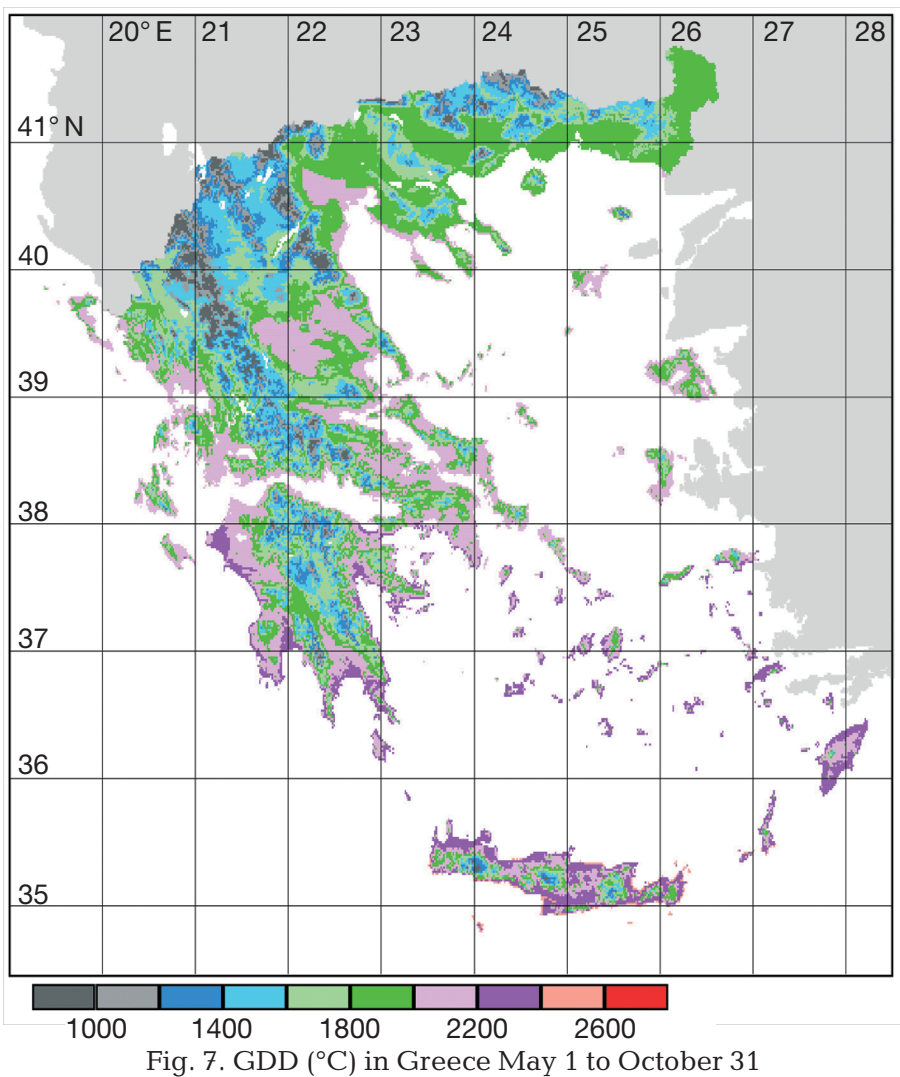

If the cultivating period is extended by 1 mo at the beginning and $1 \mathrm{mo}$ at the end (Fig. 4), the distribution of accumulated GDD shows that all cultivated areas of the country tend to have very high values (1600 to 2400), which covers the demands of all the plants cultivated in the country.

According to these results, Greece is characterized by favorable thermal conditions for the cultivation of high productivity crops.

\section{LITERATURE CITED}

Austin RB (1990) Prospects for genetically increasing the photosynthetic capacity of crops. In: Zelitch I, Allen NS (eds) Perspectives in biochemical and genetic regulation of photosynthesis. Allan R. Liss, New York, p 305-409

Baker JT, Pinter PJ, Reginato RJ, Kanemasu ET (1986) Effects of temperature on leaf appearance in spring and winter wheat cultivars. Agron J 78:605-613

Bakker JC, Van Uffelen JAM (1988) The effect of diurnal temperature regimes on growth and yield of glasshouse sweet pepper. Neth J Agric Sci 36:201-208

Court A (1974) The climate of the conterminous United States. In: Bryson RA, Hare FK (eds) World survey of climatology, vol. 11. Elsevier, New York, p 193-261

Cross HZ, Zuber MS (1972) Prediction of flowering dates in maze based on different methods of estimating thermal units. Agron J 64:351-355

Curtis BC, Rajaram S, Gómez Macpherson H (eds) (2002)

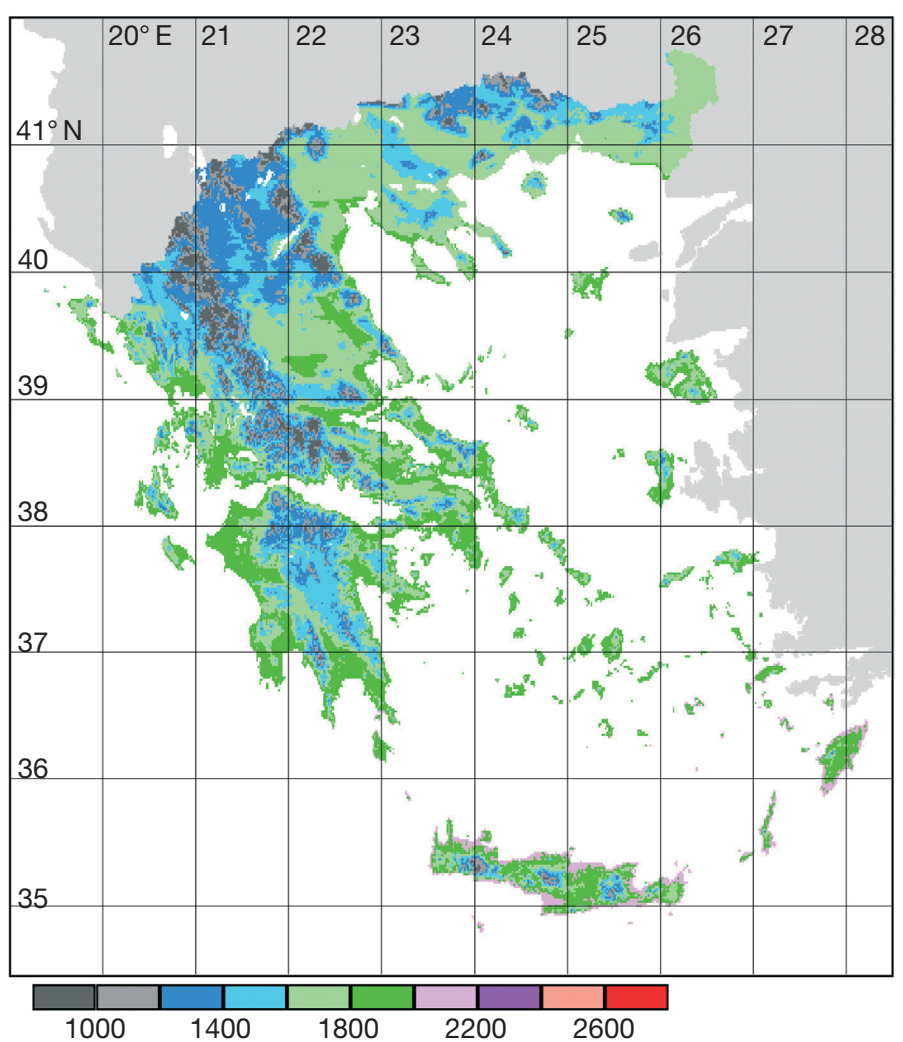

Fig. 8. GDD $\left({ }^{\circ} \mathrm{C}\right)$ in Greece May 1 to September 30

Bread wheat-improvement and production. Plant Production and Protection Series, FAO, Rome

Darby HM, Lauer JG (2002) Harvest date and hybrid influence on corn forage yield, quality, and preservation. Agron J 94:559-566

Gilmore EC, Rogers JS (1958) Heat units as a method of measuring maturity in corn. Agron J 50:611-615

HNMS (1978-1987) Monthly Climatological Bulletin. Hellenic National Meteorological Service, Athens

Masle J, Doussinalout G, Farkuhar GD, Sun B (1989) Foliar stage in wheat correlates better to photothermal time than to thermal time. Plant Cell Environ 12:235-247

Masoni A, Ercoli L, Massantini F (1990) Relations between number of days, GDD and photothermal units and growth in wheat (Triticum aestivum L.) according to seeding time. Agric Mediterr 120:41-51

Matzarakis A, Balafoutis C (2004) Heating degree days as an index of energy consumption. Int J Climatol 24:1817-1828

Matzarakis A, Katsoulis VB (2006) Sunshine duration hours over the Greek region. Theor Appl Climatol 83:107-120

McMaster GS, Smika DE (1988) Estimation and evaluation of winter wheat phenology in the central Great Plains. Agric For Meteorol 43:1-18

McMaster GS, Wilhelm WW (1997) Growing degree-days: one equation, two interpretations. Agric For Meteorol 87:291-300

McMaster GS, Wilhelm WW, Bartling PNS (1994) Irrigation and culm contribution to yield and yield components of winter wheat. Agron J 86:1123-1127

Perry KB, Wehner TC, Johnson GL (1986) Comparison of 14 methods to determine heat unit requirements for cucumber harvest. Hortscience 21:419-423

Wang JY (1960) A critique of the heat unit approach to plant 
response studies. Ecology 41:785-790

Wilhelm WW, McMaster JS (1995) The importance of the phyllochron in studying the development of grasses. Crop Sci 35:1-3

Wilhelm WW, Schepers LN, Mielke JS, Doran JW, Ellis JR, Stroup WW (1987) Dryland maize development and yield resulting from tillage and nitrogen fertilization practices.
Soil Tillage Res 10:167-179

Wilhelm WW, Bouserzour H, Power JF (1989) Soil disturbance - residue management effect on winter wheat growth and yield. Agron J 81:581-588

Wolf S, Rudish J, Marani A, Rekah Y (1986) Predicting harvest date of processing tomatoes by a simulation model. J Am Soc Hortic Sci 111:11-16
Appendix 1. FORTRAN code for calculation of growing degree days

WRITE $\left({ }^{*},{ }^{*}\right)^{\prime}$ GIVE THE NUMBER OF ROWS AND COLUMNS $R E A D(*, *) N, L$ $D O 81 I=1, N$

$81 \operatorname{READ}(7,2) \operatorname{KODE}(I),(\operatorname{TEM}(I, J), J=1, L)$

2 FORMAT(I5,31F4.1)

DO $100 \mathrm{I}=1, \mathrm{~N}$

DO $101 \mathrm{~J}=1, L$

IF(TEM(I,J).LT.10.0) GOTO 700

$\operatorname{IF}(T E M(I, J) . L E .30 .0)$ GOTO 701

$\operatorname{IF}(\operatorname{TEM}(I, J) . G T .30 .0)$ GOTO 702

$700 \operatorname{TEM} 1(I, J)=10.0$

GOTO 101

$701 \operatorname{TEM} 1(I, J)=\operatorname{TEM}(I, J)$

GOTO 101

$702 \operatorname{TEM} 1(I, J)=30.0$

GOTO 101

101 CONTINUE

100 CONTINUE

do $555 I=1, N$

$555 \operatorname{WRITE}(8,3) \operatorname{KODE}(I),(\operatorname{TEM} 1(I, J), J=1, L)$

3 FORMAT(I5,31F5.1)

CLOSE (7)

CLOSE (8)

STOP

END
Appendix 2. FORTRAN code used to estimate cumulative daily values of growing degree days using daily maximum and minimum air temperature
REAL ELEM1(30,31),ELEM2(30,31), S(1000)

INTEGER YEAR(30)

CHARACTER*2O NAME1,NAME2,NAME3

WRITE $\left({ }^{*},{ }^{*}\right)$ 'GIVE THE NAME OF THE output FILE'

$\operatorname{READ}\left({ }^{*},{ }^{*}\right)$ NAME1

WRITE $\left({ }^{*},{ }^{*}\right)$ 'THE NAME OF THE MAX DATA FILE'

$R E A D\left({ }^{*}, *\right)$ NAME2

WRITE $\left({ }^{*},{ }^{*}\right)$ 'THE NAME OF THE MIN DATA FILE'

READ $\left({ }^{*}, *\right)$ NAME3

OPEN $\left(9, F I L E=N A M E 1, S T A T U S={ }^{\prime} N E W^{\prime}\right)$

OPEN $\left(8, F I L E=N A M E 2, S T A T U S={ }^{\prime} O L D^{\prime}\right)$

OPEN $\left(7, F I L E=N A M E 3, S T A T U S={ }^{\prime} O L D^{\prime}\right)$

WRITE $\left({ }^{*},{ }^{*}\right)$ 'GIVE THE NUMBER OF ROWS AND COLUMNS'

$R E A D(*, *) N, L$

write $\left({ }^{*},{ }^{*}\right)$ 'GIVE THE TOTAL OF THE PREVIUS MONTH'

$R E A D(*, *)$ VALUE

$m 1=0$

$S 1=0.0$

DO $100 I=1, N$

$R E A D(8,1) Y E A R(I),(\operatorname{ELEM} 1(I, J), J=1, L)$

$100 R E A D(7,1) Y E A R(I),(E L E M 2(I, J), J=1, L)$

1 FORMAT(I5,31F5.1)

DO $101 I=1, N$

DO $102 J=1, L$

$M 1=M 1+1$

IF(I.GT.1) GOTO 5

IF(J.GT.1) GOTO 5

$S(M 1)=V A L U E+(((E L E M 1(I, J)+E L E M 2(I, J)) / 2)-10.0)$ GOTO 6

$5 S(M 1)=S(M 1-1)+(((E L E M 1(I, J)+E L E M 2(I, J)) / 2)-10.0)$

GOTO 6

6 CONTINUE

102 CONTINUE

101 CONTINUE

$M=N^{*} L$

DO $113 I=1, M$

113 WRITE $(9,333) S(I)$

333 FORMAT(F7.1)

CLOSE (9)

CLOSE(8)

$C L O S E(7)$

STOP

END 